\title{
AWARNESS OF DIABETES MELLITUS AMONG AFRICAN TRADITIONAL HEALERS IN THE NELSON MANDELA METROPOLE
}

\section{Mea Van Huyssteen}

B Pharm, MSc

Postgraduate pharmacy masters student, Department of Pharmacy, University of Port Elizabeth

\section{Millidhashni Reddy}

B Pharm

Postgraduate pharmacy masters student, Department of Pharmacy, University of Port Elizabeth

\section{Nadasen T Naidoo}

BSc Pharm Hons, MSc, PhD, MPS

Dean, Faculty of Health Sciences, University of Port Elizabeth

\section{Shirley-Anne Boschmans \\ Dip Pharm, MSc \\ Senior Lecturer, Department of Pharmacy, University of Port Elizabeth}

\section{Jane McCartney}

Dip Pharm, MSc

Lecturer, Department of Pharmacy, University of Port Elizabeth

\author{
Maryna van de Venter \\ BSc Hons, MSc, PhD \\ Lecturer, Department of Biochemistry and Microbiology, University of Port Elizabeth \\ Corresponding author: bcamvd@upe.ac.za
}

Key Words: traditional healer; Diabetes mellitus; interactive workshops; Nelson Mandela Metropole; South Africa

\begin{abstract}
Diabetes mellitus, a chronic illness, affects approximately $8 \%$ of black South Africans. Traditional healers are an integral part of the lifestyle of the African people. Approximately $80 \%$ of black patients consult a western doctor only after having consulted a traditional healer, yet traditional healers remain an untapped resource in South Africa. The primary objective of the study was to determine the clinical knowledge pertaining to diabetes mellitus of traditional healers in the Nelson Mandela Metropole (NMM), and to educate the healers on diabetes mellitus through the medium of interactive workshops. Three workshops were held with the healers over a seventeen-month period. The target population consisted of all traditional healers of the NMM interested in participating in the research project. The results obtained indicated that healers of the NMM had a basic knowledge about diabetes and a willingness to learn more about conventional aspects of the disease. At a feedback workshop the healers indicated that they were using the information gained during preceding workshops and that they have begun imparting the knowledge gained to other traditional healers and to their apprentices. A relationship has been established between healers of the NMM and the University of Port Elizabeth (UPE) and Port Elizabeth Technicon.
\end{abstract}

\section{OPSOMMING}

Diabetes mellitus, 'n chroniese siekte, affekteer na raming $8 \%$ van Suid-Afrika se swart bevolking. Tradisionele 
genesers is ' $n$ integrale deel van die lewenswyse van dié bevolkingsgroep. Bykans $80 \%$ van alle swart pasiënte besoek ' $n$ tradisionele geneser voor hulle hul tot ' $n$ westerse geneesheer wend. Ten spyte hiervan bly tradisionele genesers ' $n$ onbenutte hulpbron in Suid-Afrika. Die primêre doelwitte van dié navorsing was om die kliniese kennis van tradisionele genesers ten opsigte van diabetes te bepaal en om hulle verder oor diabetes te onderrig deur middel van interaktiewe werkswinkels. Drie werkswinkels is oor 'n tydperk van sewentien maande gehou. Die teikengroep was 'n groep genesers wat geïnteresseerd was om aan die navorsing deel te neem. Die navorsing toon dat genesers in die NMM oor ' $n$ basiese kennis van diabetes mellitus beskik en gewillig was om meer van die konvensionele aspek van diabetes te leer. In 'n terugvoerbespreking het die genesers te kenne gegee dat die inligting wat hulle tydens die werkswinkels verkry het, aktief deur hulle gebruik word, asook oorgedra word aan ander genesers en vakleerlinge. Die navorsing het die basis vir 'n goeie verstandhouding tussen die tradisionele genesers, die Universiteit van Port Elizabeth and die Port Elizabeth Technikon gelê.

\section{INTRODUCTION}

Diabetes mellitus is a chronic illness associated with disability and increased mortality. Therefore, diabetes should be a major cause of public health concern, especially in South Africa, where approximately one million people have been diagnosed with the disease. The prevalence among the black population has been estimated to be $8 \%$ and is rising (Leuner, 2000:415). This may be attributed to the increasing rate of urbanisation (Levitt, Zwarenstein, Doepfmer, Bawa, Katezenellenbogen \& Bradshaw, 1996:1014). City life is associated, amongst other factors, with a sedentary lifestyle and poor eating habits. People often consume unhealthy foods that have a high sugar and fat content, which can influence body weight adversely. Increased body weight is a major risk factor for developing diabetes mellitus (Khan, 1994:1068). Furthermore, overweight diabetic patients have a greater risk of developing cardiac complications such as heart failure, and hypertension (Working Group of the National Diabetes Advisory Board, 1997:507).

Lifestyle modification plays a vital role in decreasing the incidence of diabetic complications and thus improving quality of life of the diabetic patient. In order to encourage lifestyle modification, the patient must be counselled effectively (American Diabetes Association, 2002:s33). Patient education is a cost-effective tool in preventative medicine. Diabetic control can only be achieved once the patients are knowledgeable about their disease state and assume responsibility for their health. Therefore, it is incumbent on health care professionals to ensure that all diabetic patients are educated on matters relating to their illness. Furthermore, it is imperative that all avenues for increas- ing awareness of the seriousness of this disease be explored (Working Group of the National Diabetes Advisory Board, 1997:498).

\section{BACKGROUND TO THE STUDY}

Traditional healers form an integral part of the lifestyle of the African people. They are highly regarded by their communities, as they are the custodians of the African belief system (Abdool Karim, Ziqubu \& Arendse, 1994:14). Therefore, collaboration between health care workers and traditional healers may be the answer to providing effective health education to the majority of South Africans. The focus must be to broaden the knowledge of the traditional healer regarding health issues like diabetes mellitus.

At the end of 2000, the departments of Biochemistry and Microbiology and Pharmacy at the University of Port Elizabeth (UPE) initiated a research programme involving African traditional healers. Included in this venture was the department of Biomedical Science from the Port Elizabeth Technicon. Mister Mike Pantsi, chairperson of the Imbewu Community Volunteers, a non-governmental organisation, established contact between the healers and the tertiary institutions.

\section{PROBLEM STATEMENT}

Eighty percent of black patients visit a traditional healer before consulting a Western doctor (Abdool Karim et al. 1994:14). Currently the ratio of traditional healers to patients in Africa is estimated to be between 1:200 and $1: 400$, while the ratio of qualified medical doctors to patients is estimated to be 1:20 000 (Burcher \& Ho, 2002). However, the two to three hundred thousand tra- 
ditional healers present in South Africa do not have formal registration with a central or controlling body and training has not been standardised (Kale, 1995:1185). It was only in April 2003 that the Traditional Health Practitioners Bill was drafted and published in the Government Gazette (Draft Bill no. 24704, 2003:3). This Bill provides for a regulatory framework to ensure the efficacy, safety and quality of traditional health care services.

African traditional healers could provide an enormous potential to educate diabetic patients, if the healers themselves have the correct training (Clarke, 1998). Thus, it is imperative that the current knowledge of traditional healers on diabetes mellitus be evaluated. This will help determine what areas of knowledge are deficient so that the healers can receive adequate education on the disease, which can be passed on to their patients.

\section{OBJECTIVES OF THE STUDY}

The purpose of the study was to:

- determine the clinical knowledge, pertaining to diabetes mellitus, of the traditional healer;

- increase the awareness of diabetes mellitus among traditional healers;

- empower the traditional healer through education; and

- encourage traditional healers to counsel diabetic patients on lifestyle modification.

\section{METHODOLOGY}

It was important for the method chosen to allow for two-way communication. This would encourage interaction between the researchers and the traditional healers. Research on collaboration between traditional healers and health care professionals recommends that activities such as seminars and workshops be planned as this will allow both parties to express their views, establish common goals and develop ways of using traditional healers in primary care teams (Setswe, 1999:59). Therefore, interactive workshops were identified as the most suitable research tool.

\section{Design}

The study was explorative, interactive and descriptive in design. The knowledge of traditional healers pertaining to diabetes mellitus was explored through the medium of interactive workshops.

\section{Data generating methods}

The interactive workshops included both group discussions and oral presentations. Notes, summarising the oral presentations, were provided to all participating healers. These notes were presented in English and Xhosa. Translators eliminated the language barrier during the group discussions.

Group discussions formed an integral part of the workshops and were implemented to ensure two-way communication; a number of the healers were illiterate and a questionnaire-based interaction would therefore not have been appropriate.

A group discussion can be defined as a qualitative method of data gathering, which may be used to explore new areas of research. Group discussion is an important tool for cross-cultural research. A major advantage of this method was that the healers were allowed to talk for themselves, with minimal input or influence from the researchers. Furthermore, the collective peer support of the group gave the healers a greater sense of confidence than if they were facing the researchers alone. However, a major disadvantage is that the data obtained from the workshops may not be extrapolated to all healers in South Africa as only healers that were interested in the research project attended the workshops (Godsell, 1983:9-12).

\section{Target population}

The target population of the study consisted of traditional healers from the Nelson Mandela Metropole (NMM) who were interested in participating in the research project. All the healers were members of either Nyangazezizwe or the Traditional Doctors of the Eastern Cape Task Team. Both these organisations are situated in the NMM. The two local chairpersons of these bodies were requested to encourage healers from their organisations to participate in the research programme. Nyangazezizwe is a non-governmental organisation affiliated with the association for the Promotion of Traditional Medicine in South Africa (PROMETRA). 
PROMETRA has international equivalents. The Traditional Doctors of the Eastern Cape Task Team is a governmental organisation linked to the local Department of Health. Interaction with both governmental and non-governmental organisations ensured that the majority of traditional healers from the NMM were included in the study.

\section{Ethical issues}

Participation of the traditional healers in the research projects/workshops was voluntary. No comment on ethical issues is included in the article as the authors considered it irrelevant since participation was by choice. Responses from the individual interviews held with the traditional healers were kept confidential, and all responses were analysed and presented in a group.

\section{Limitations of the study}

- The target population was not representative of all traditional healers in the NMM as only those healers who were interested in the research project participated in the workshops.

- Only a limited number of healers could attend the workshops. Limited funding was available (the departments of Biochemistry and Microbiology at UPE funded transport for the healers to and from the workshop venues). Secondly, the venues could only seat a limited number of people. Finally, a language barrier existed between the traditional healers (Xhosa speaking) and the researchers (English speaking). As only three translators were available at each workshop, the number of healers was limited to facilitate and make the discussions more practical.

- At times during the planning and preparation of the workshops, communication between the researchers and the healers and amongst the healers themselves was poor.

- Field notes summarising the discussions during the workshops, were written by hand. Recording the group discussions would have been easier but tape recorders were not used for the purpose of data collecting, to obviate any caused suspicion on the part of the traditional healers regarding the intentions of the researchers.

\section{RESULTS AND DISCUSSION}

The diabetes workshops formed part of a series of workshops titled as "Diabetes: Different Views."Three main workshops were presented over a period of seventeen months. During this period, other workshops and meetings were held with the traditional healers to promote and develop a strong partnership between the healers and the researchers.

Altogether 51 traditional healers in the Eastern Cape participated in one or more of the aforementioned three diabetes workshops. There is no reliable data on the number of traditional healers currently practising in the Eastern Cape Region. It is therefore not possible to estimate what percentage of the total number of healers in the Eastern Cape the participating healers represented.

Continuity regarding the healers attending the workshops was poor: only three healers attended all three workshops. This could be ascribed to a number of factors. Firstly, not all the healers who attended the first workshop were in town or available at the time of the following workshops. Secondly, some healers only became aware of the project after the first workshop. This explains the increasing number of attendees at the second (nineteen attendees compared to eleven for workshop 1) and third (28 attendees) workshops. Thirdly, because the number of healers was limited to approximately 25 healers per workshop and the chairpersons of the Traditional Healers Associations wanted to expose the majority of their members to the workshops, they allowed different healers to attend different workshops. This led to poor uniformity of the sample population. Lastly, the communication system between the researchers and the healers and amongst the healers themselves was inadequate, as a result of which researchers were not able to reach the healers at crucial times. Messages often reached the healers too late.

\section{Workshop 1}

The first workshop was held at the KwaZakhele Day Clinic. The workshop represented the first official research meeting between the investigators, eleven in- 
terested healers and a nurse (also a traditional healer) from the Department of Health.

The initial step was to determine traditional practices and perceptions regarding diabetes management. The information gathered during the first meeting was used to develop the content of the ensuing workshops.

The meeting was in the form of an unstructured group interview and helped the researchers determine the clinical knowledge of the traditional healers regarding diabetes. The healers' perceptions of the causes of diabetes, signs and symptoms and recommended lifestyle modifications were established. Data capturing was achieved by taking notes and the data collected, were used to design the contents of the subsequent workshops.

The findings of workshop 1 are summarised in Table 1. The actual number of healers that mentioned each cause, sign and symptom and lifestyle modification could not be quantified. This is because the workshops were held in the form of informal discussions and the healers were not questioned individually. The group reached consensus as the discussion progressed. The traditional healers had a satisfactory picture of the symptomology associated with diabetes.

Individual interviews were also held with five traditional healers, who attended the first meeting, to ensure that the data obtained was a true reflection of the group. These findings are summarised in Table 2.

To ensure credibility, the findings were compared to a similar study on traditional healers conducted in the Limpopo Province (previously known as the Northern Province) by Peltzer, Khosa, Lekhuleni, Madu, Cherian and Cherian (2001:43, 44). The results of the comparison are summarised in Table 3.

The traditional healers' description of diabetes was similar to that of conventional medicine. Signs and symptoms were closely aligned to those documented in medical literature. However, the healers did not exhibit

Table 1: A summary of the traditional healers' view of diabetes, obtained via group consensus during the first workshop

\begin{tabular}{|c|c|}
\hline \multicolumn{2}{|c|}{ Perceived causes of diabetes mellitus } \\
\hline $\begin{array}{l}\text { Diet } \\
\text { Psychological } \\
\text { Age } \\
\text { Cultural }\end{array}$ & $\begin{array}{l}\text { Too much tea with sugar; fatty foods } \\
\text { Stress and worries; no rest } \\
\text { People older than } 30 \text { years; the elderly } \\
\text { Coastal vicinity } \\
\text { Part of the "calling" process (The "sign" a person receives indicating that } \\
\text { the ancestors are calling them to become a sangoma. This "calling" } \\
\text { manifests in the form of a disease, like diabetes). }\end{array}$ \\
\hline \multicolumn{2}{|c|}{ Signs and symptoms of diabetes mellitus } \\
\hline $\begin{array}{l}\text { Swelling of the } \\
\text { Foot ulcers tha } \\
\text { Body bruises e } \\
\text { Decline in sext } \\
\text { "Crawling" in th }\end{array}$ & $\begin{array}{l}\text { y and face } \\
\text { y spread to the rest of the leg (were referred to as "pimples") } \\
\text { ctivity } \\
\text { gs } \\
\text { ght }\end{array}$ \\
\hline \multicolumn{2}{|c|}{ Recommended lifestyle modifications } \\
\hline Exercise & $\begin{array}{l}\text { Eat: fish, skinless chicken, vegetables, fruit and milk } \\
\text { Avoid: tea, sugar, fats, red meat and starch } \\
\text { Any type of exercise for } 30 \text { minutes in the morning and evening } \\
\text { Elevate the legs }\end{array}$ \\
\hline
\end{tabular}


Table 2: Summary of individual interviews

\begin{tabular}{|c|c|c|}
\hline Question & Answers & $\begin{array}{l}\text { Frequency of similar } \\
\text { responses among the } \\
\text { five healers }\end{array}$ \\
\hline $\begin{array}{l}\text { Signs and } \\
\text { symptoms of } \\
\text { diabetes mellitus }\end{array}$ & $\begin{array}{l}\text { Sleepiness/drowsiness/weakness } \\
\text { Swollen legs/ankles/feet } \\
\text { Sores on feet } \\
\text { Genital itching } \\
\text { Dry mouth/thirsty } \\
\text { Poor wound healing } \\
\text { Persistent hunger } \\
\text { Sweating } \\
\text { Difficulty breathing/Shortness of } \\
\text { breath } \\
\text { Dizziness } \\
\text { Polyuria } \\
\text { Diarrhoea/Vomiting } \\
\text { Headache }\end{array}$ & $\begin{array}{l}* * * * \\
\star * * \\
* * * \\
* * * \\
* * * \\
* * * \\
* * \\
* * \\
* * \\
* \\
* \\
* \\
*\end{array}$ \\
\hline $\begin{array}{l}\text { Causes of diabetes } \\
\text { mellitus }\end{array}$ & $\begin{array}{l}\text { Diet (too much sugar) } \\
\text { Family history } \\
\text { Stress and worry (poverty) } \\
\text { Witchcraft } \\
\text { Gain weight (then lose) }\end{array}$ & $\begin{array}{l}* * * * * \\
* * * \\
* * \\
* \\
*\end{array}$ \\
\hline Advice to patient & $\begin{array}{l}\text { Diet } \\
\text { Exercise } \\
\text { Relax/rest } \\
\text { Keep weight constant/lose weight } \\
\text { Check sugar (glucose at } \\
\text { pharmacy/clinic) } \\
\text { Stop smoking/stop alcohol intake }\end{array}$ & $\begin{array}{l}* * * * \\
* * * \\
* * * \\
* * \\
* \\
*\end{array}$ \\
\hline
\end{tabular}

any understanding of signs and symptoms associated with hypo- and hyperglycaemia. The perceived causes of diabetes differed with regard to the pathophysiology of diabetes. The healers also did not identify the intrinsic causes of diabetes mellitus (for example, insulin deficiency) (Steil, 1999:1219).

In summary, the traditional healers displayed a basic knowledge of the condition and a keen interest to learn more about the disease.

\section{Workshop 2}

The aim of this workshop was to supplement the knowledge pertaining to diabetes mellitus of the traditional healers, as determined in the previous workshop. Nineteen healers attended this workshop, held at the Port Elizabeth Health Resource Centre.

The workshop comprised of an oral presentation on the pathogenesis of diabetes mellitus, diabetic complica- 
Table 3: Comparison between the research findings of the study conducted with healers of the NMM and the research findings of Peltzer et al. (2001:43-44) conducted with healers from the Limpopo Province

\begin{tabular}{|c|c|}
\hline $\begin{array}{l}\text { Common } \\
\text { statements }\end{array}$ & $\begin{array}{l}\text { Causes: Too much sugar, stress, lack of relaxation } \\
\text { Signs and Symptoms: Swelling, weakness, sweating, sexual } \\
\text { dysfunction, skin colour changes and poor eyesight } \\
\text { Lifestyle Changes: Diet }\end{array}$ \\
\hline $\begin{array}{l}\text { Statements } \\
\text { made by NMM } \\
\text { healers, but not } \\
\text { by Limpopo } \\
\text { Province healers }\end{array}$ & $\begin{array}{l}\text { Causes: Too much fatty foods and age related diabetes } \\
\text { Signs and Symptoms: Foot ulcers }\end{array}$ \\
\hline $\begin{array}{l}\text { Statements } \\
\text { made by } \\
\text { Limpopo } \\
\text { Province } \\
\text { healers, but not } \\
\text { by NMM healers }\end{array}$ & $\begin{array}{l}\text { Causes: Alcohol consumption, too much salt in the diet, genetic } \\
\text { predisposition } \\
\text { Signs and symptoms: Foul smelling urine, increased heart rate, } \\
\text { reduced body weight, painful body, temper outbursts and aggression, } \\
\text { dizziness and headache, decreased/increased appetite, diarrhoea and } \\
\text { constipation, persistent thirst }\end{array}$ \\
\hline $\begin{array}{l}\text { Observations } \\
\text { lacking in both } \\
\text { groups }\end{array}$ & $\begin{array}{l}\text { Causes: No reference made to the true pathophysiology of diabetes } \\
\text { Signs and symptoms: Polyuria, polydipsia and polyphagia were not } \\
\text { identified as the major problems of diabetes } \\
\text { Lifestyle changes: Weight loss did not feature as an important change }\end{array}$ \\
\hline
\end{tabular}

tions, lifestyle modification including dietary guidelines and exercise, problems encountered in the public sector and possible solutions to these problems (American Diabetes Association, 2002:s33-s46; Goodman, Zwarenstein, Robinson \& Levitt, 1997:308).

The traditional healers apparently believed that diabetes could be cured. They enquired about the conventional view of this belief. The researchers explained that it was possible to manage diabetes without medication, only if the patient adheres to lifestyle changes, as this will ensure adequate control (Working Group of the National Diabetes Advisory Board, 1997:505). The data gathered in workshop 1 indicated that the healers did not have an understanding of hypo- and hyperglycaemia. These topics formed an important part of the discussion in workshop 2. The healers were given information regarding the signs and symptoms of low and high blood glucose and how to treat these problems (Working Group of the National Diabetes Advisory Board, 1997:499; Steil, 1999:1233). The healers recalled that patients presented with symptoms of hypo- and hyperglycaemia and participated in the discussion.

Many of the healers enquired about glucose readings and their relation to adequate and poor diabetic control. This was encouraging, as it indicated that they were interested in the conventional methods of treating and diagnosing diabetic patients. The concept of ideal, acceptable and compromised blood glucose levels was discussed with the healers (Working Group of the National Diabetes Advisory Board, 1997:500). Due to a lack of medical resources, the healers are unable to monitor patients via glucose testing. The healers mentioned that they refer patients to the primary health care setting. The interest shown by the healers with regard to blood glucose levels and the referral of patients to the primary health care level was a deciding factor for the discussion of the National Guidelines in the third workshop (Working Group of the National Diabetes Advisory Board, 1997:497-509). 


\section{Workshop 3}

The final workshop that was attended by 28 healers was also held at the Port Elizabeth Health Resource Centre.

This workshop included a detailed discussion following an oral presentation on the National Diabetic Guidelines for the management of patients with Type 2 diabetes mellitus at primary health care level (Working Group of the National Diabetes Advisory Board, 1997:497-509). The concept of monitoring body mass index was explained and demonstrated to the traditional healers. The importance of a strict weight control programme for diabetic patients was emphasised. The researchers explained that diabetic control generally improved with a decrease in the patient's body weight and that being overweight was indicative of an unhealthy lifestyle (American Diabetes Association, 2002:s35).

The National Guidelines were summarised and presented to the healers in the form of tables. Aspects of patient education were re-emphasised, inter alia the identification of symptoms of hypo- and hyperglycaemia (Working Group of the National Diabetes Advisory Board, 1997:502-503).

During workshops 2 and 3, an awareness of the seriousness of diabetes mellitus was created amongst the healers through discussions on the physiology of diabetes mellitus and the occurrence and implications of diabetic complications (American Diabetes Association, 2002:s39-s44; Steil, 1999:1219). The healers were equipped to counsel patients on the importance and effectiveness of lifestyle modification.

\section{Evaluation of workshops}

The workshops were evaluated and, although written interactions were not deemed ideal, the traditional healers were requested to complete an evaluation form at the end of workshops 2 and 3 . The healers had no objections to evaluating the workshops, and all the attendees from workshops 2 and 3 completed an evaluation form. The questionnaires were available in both Xhosa and English, and translators assisted the healers if they experienced any problems in understanding or completing the questionnaire. The evalu- ation forms contained mainly open-ended questions; giving the healers an opportunity to express which part of the workshop they enjoyed the most. The feedback from the healers was overwhelmingly positive. The feeling amongst the healers was that these workshops were beneficial to the traditional healing practice and that research investigating possible methods of collaboration between traditional healers and medical professionals is essential to the South African setting.

However, analysing the evaluation forms presented problems because the healers were not specific in answering the questions and thus no quantitative data about the contents of the workshops could therefore be obtained.

It is recommended, that if evaluation forms are again used in future research, they contain closed ended questions (Yes, No, Maybe) or different options with regard to the topics discussed. For example, instead of asking which part of the workshop the respondent enjoyed the most, a variety of topics discussed during the workshop (for example, diet, exercise and body mass index) could be provided next to check boxes and the healers can highlight the applicable option.

An alternative method to assess the effectiveness of workshops is through a meeting with the participants after they have been given the opportunity to apply the knowledge gained. This interaction can be in the form of an informal feedback session. Three months after the workshops had been conducted, this method was used with 20 traditional healers who each attended at least one of the three diabetes workshops, to assess if they were applying the information obtained in their traditional practices. All the healers confirmed that they were implementing the information in their practices and were also imparting their knowledge to their apprentices. In addition, the healers requested that the workshops be repeated to accommodate those who did not have the opportunity to attend the first series of workshops.

\section{CONCLUSION}

The research findings can be summarised as follows:

- The healers were aware of diabetes and had a basic knowledge of the disease; their perceptions 
differed slightly in terms of pathogenesis and signs and symptoms from conventional medicine.

- The awareness level among the traditional healers of the importance of monitoring and providing education to diabetic patients was raised substantially.

- The healers received information based on the National Diabetic Guidelines that they could apply in their interaction with diabetic patients (Working Group of the National Diabetes Advisory Board, 1997:497-509). The healers are now adequately empowered to counsel diabetic patients.

- The healers are imparting the knowledge obtained from workshops 2 and 3 to other traditional healers and to their apprentices.

With the passing of the Traditional Health Practitioners Bill the government has taken a step forward in recognising the influence that the traditional healer has on the black population of South Africa (Draft Bill no. $24704,2003: 3$ ). Traditional healers can make a significant contribution to diabetic care in South Africa. Educational programmes will be essential to address certain aspects. With the traditional healers' willingness to learn, the implementation of such programmes should not be difficult.

\section{ACKNOWLEDGEMENTS}

The authors thank:

- the traditional healers of the NMM, for their enthusiasm and participation in the workshops;

- ms Tandiwe Mazamane and ms Fezeka Kosi, who played a leading role in contacting the traditional healers;

- mr Mike Pantsi, who established the contact between the healers and the researchers; and

- the University of Port Elizabeth, the South African Medical Research Council and the National Research Foundation (Project number 2050363), for their financial assistance.

\section{REFERENCES}

ABDOOL KARIM, SS; ZIQUBU, T \& ARENDSE, R 1994: Potential for a health care partnership between African traditional healers and biomedical personnel in South Africa. South African Medical Journal, Dec (insert); 84(12):14-15.
AMERICAN DIABETES ASSOCIATION 2002: Standards of medical care for patients with diabetes mellitus. Diabetes Care, 25 (Suppl. 1):33-49.

BURCHER, S \& HO, M-W 2002: Global strategy for traditional medicine. Institute of Science in Society ISIS Report. http://www.isis.org.uk/GSFTM.php (date accessed: 10/11/2003).

CLARKE, E 1998: The collaboration between traditional healers and the Department of Health. Up Date, issue no. 37, October. http:// www.hst.org.za/update/37/policy1.htm (date accessed: 03/02/2003). DRAFT BILL NO. 24704, 11 April 2003. Traditional Health Practitioners Bill (In: Government Gazette, RSA, Volume 454, Pretoria).

GODSELL, G 1983: Group discussion as a means of data collection (In: Data Collection: A problem area in Human Sciences Research. Taken from: Research Bulletin, Journal for the South African Plan for Research. André Bouwer Printers, Pretoria, South Africa; pp 9-12). GOODMAN, GR; ZWARENSTEIN, MF; ROBINSON, II \& LEVITT, NS 1997. Staff knowledge, attitudes and practices in public sector primary care of diabetes in Cape Town. South African Medical Journal, 87(3):305-309.

KALE, R 1995: South Africa's health: Traditional healers in South Africa: A parallel health care system. British Medical Journal, 310(6988):1182-1185.

KHAN, CR 1994: Insulin action, diabetogenes, and the cause of type II diabetes. Diabetes, 43:1066-1084.

LEUNER, S 2000: Diabetes care in South Africa. Specialist Medicine, 22(7):410-415.

LEVITT, NS; ZWARENSTEIN, MF; DOEPFMER, S; BAWA, AA; KATEZENELLENBOGEN, J \& BRADSHAW, D 1996: Public sector primary care of diabetes - a record review of quality of care in Cape Town. South African Medical Journal, 86(8):1013-1017.

LEVITT, NS; BRADSHAW, D; ZWARENSTEIN, MF; BAWA, AA \& MAPHUMOLO, S 1997: Audit of public sector primary diabetes care in Cape Town, South Africa: High prevalence of complications, uncontrolled hyperglycaemia and hypertension. Diabetic Medicine, 14(12):1073-1077.

PELTZER, K; KHOSA, LB; LEKHULENI, ME; MADU, SN; CHERIAN, VI\& CHERIAN, L 2001: Concepts and treatment of diabetes among traditional and faith healers in the Northern Province, South Africa. Curationis, 24(2):42-47.

SETSWE, G 1999: The role of traditional healers and primary health care in South Africa. Health SA Gesondheid, 4(2):56-60.

STEIL, CF 1999 : Diabetes Mellitus (In: DIPIRO, JT; TALBERT, RL; YEE, GC; MATZKE, GR; WELLS, BG \& POSEY, LM (Eds) 1999: Pharmacotherapy: A pathophysiologic approach; fourth edition. New York: McGraw-Hill; pp 1219-1243).

WORKING GROUP OF THE NATIONAL DIABETES ADVISORY BOARD 1997: Guidelines for the management of type II (non-insulin dependent) diabetes mellitus at the primary care level in South Africa. South African Medical Journal, 87(4):497-512. 